\title{
Gut Microbiota Manipulation as a Tool for Colorectal Cancer Management: Recent Advances in Its Use for Therapeutic Purposes
}

\author{
Federica Perillo ${ }^{1, \dagger}$, Chiara Amoroso ${ }^{1, \dagger}$, Francesco Strati ${ }^{1, * \mathbb{C}}$, Maria Rita Giuffrè ${ }^{1}$, \\ Angélica Díaz-Basabe ${ }^{1,2}(\mathbb{D})$, Georgia Lattanzi ${ }^{1,2}$ and Federica Facciotti ${ }^{1, *(D)}$ \\ 1 Department of Experimental Oncology, IEO European Institute of Oncology IRCCS, 20139 Milan, Italy; \\ federica.perillo@ieo.it (F.P.); chiara.amoroso@ieo.it (C.A.); MariaRita.giuffre@ieo.it (M.R.G.); \\ angelicajulieth.diazbasabe@ieo.it (A.D.-B.); georgia.lattanzi@ieo.it (G.L.) \\ 2 Department of Oncology and Hemato-Oncology, Università degli Studi di Milano, 20135 Milan, Italy \\ * Correspondence: francesco.strati@ieo.it (F.S.); federica.facciotti@ieo.it (F.F.) \\ + These authors equally contributed.
}

Received: 13 July 2020; Accepted: 28 July 2020; Published: 29 July 2020

\begin{abstract}
Colorectal cancer (CRC) is a multifaceted disease influenced by both environmental and genetic factors. A large body of literature has demonstrated the role of gut microbes in promoting inflammatory responses, creating a suitable microenvironment for the development of skewed interactions between the host and the gut microbiota and cancer initiation. Even if surgery is the primary therapeutic strategy, patients with advanced disease or cancer recurrence after surgery remain difficult to cure. Therefore, the gut microbiota has been proposed as a novel therapeutic target in light of recent promising data in which it seems to modulate the response to cancer immunotherapy. The use of microbe-targeted therapies, including antibiotics, prebiotics, live biotherapeutics, and fecal microbiota transplantation, is therefore considered to support current therapies in CRC management. In this review, we will discuss the importance of host-microbe interactions in CRC and how promoting homeostatic immune responses through microbe-targeted therapies may be useful in preventing/treating CRC development.
\end{abstract}

Keywords: colorectal cancer; gut microbiome; live biotherapeutic products

\section{Background}

Colorectal cancer (CRC) is the third most commonly diagnosed malignancy and the fourth leading cause of cancer death in the world [1]. CRC is a heterogeneous disease with a wide range of long-term outcomes and responses to treatment. Genetic and environmental factors contribute to the etiology and progression of the disease. Several risk factors have been identified, including positive family history, smoking, alcohol intake, lifestyle, and cultural and social practices [2]. Moreover, emerging evidence suggests that diet has an important impact on the risk of CRC development [3]. Over the past three decades, molecular genetic studies have revealed some critical mutations underlying the pathogenesis of the sporadic and inherited forms of CRC [4], including mutational inactivation of the adenomatous polyposis coli (APC) tumor suppressor [5], resulting in overactivation of the $\mathrm{Wnt} / \beta$-catenin signaling pathway, dysregulated cell proliferation and adenoma development [6], or microsatellite instability, assessed with the detection of mono- and di-nucleotide tracts selected by the National Cancer Institute consensus conference $[4,7]$.

Current treatments for CRC include endoscopic and surgical local excision, downstaging preoperative radiotherapy and systemic therapy, extensive surgery for locoregional and metastatic disease, local ablative therapies for metastases, palliative chemotherapy, targeted therapy, 
and immunotherapy [8]. Although these treatments have doubled the overall survival of patients up to 3 years for advanced stages of the disease, CRC remains associated with poor prognosis and very low rates of long-term survival [9]. The development and progression of CRC are multi-factorial processes which are associated also with the progressive failure of immunosurveillance, which is the natural and/or therapy-stimulated capacity of the immune system to control cancer progression [10]. However, the role of altered mucosal immune surveillance in the development of CRC has not yet been fully understood [11].

The role of the gut microbiota in cancer biology has been increasingly recognized as an environmental factor favoring CRC development. Indeed, the gut microenvironment harbors a complex microbial ecosystem comprising approximately $3 \times 10^{13}$ bacteria and other microorganisms such as fungi, phages, archaea, and protists [12], which are confined into the intestinal lumen by the epithelial cell lining, the mucus layers, and the production of antibacterial peptides and bioactive molecules [13]. The mutual interaction between the gut microbiota and the host is further highlighted by its role in inducing immune maturation [14]. For this reason, a CRC-associated microbial dysbiosis can alter the delicate equilibrium between the gut microbiota and the host's immune system, contributing to cancer initiation and/or progression [15]. The spatial organization of multispecies bacterial communities in higher-order structures, termed biofilms, appears to be indispensable for CRC initiation. According to the adenoma-carcinoma sequence model proposed by Fearon and Vogelstein [16], microbial biofilm may be regarded as an independent "driver" at an early stage of CRC carcinogenesis, before the malignant transformation from adenoma to carcinoma. Here, we will recapitulate how the interconnection between the intestinal microenvironment, CRC onset, and the gut microbiota composition may influence therapies' outcomes. We will discuss the importance of gut microbiota modulation in CRC patients through dietary interventions as well as microbiome biomodulators, including anti-, pro-, pre-, and post-biotics and fecal microbiota transplantation, and how these therapeutic strategies can help in preventing/treating CRC.

\section{Role of Gut Microbiota in CRC}

\subsection{Pro-Tumorigenic Roles of the Gut Microbiota in CRC}

The gut microbiota has been linked to carcinogenesis and colorectal tumor progression [15]. Pathobionts (microorganisms commonly living in the gut that become harmful under certain circumstances) colonizing the intestine may produce genotoxins, metabolites that induce DNA damage, which can lead to alterations in the tumor microenvironment (TME), inducing subsequent changes in the abundance of colonic intrinsic pathogenic members (Table 1) [17]. For instance, Escherichia coli is a bacterium commonly found in the human gut. However, some strains are pathogenic and can promote disease via several virulence factors [18]. The E. coli-derived colibactin toxin, encoded by the pathogenicity island $p k s$, is frequently associated with human colorectal carcinogenesis, as demonstrated in human and animal models in which $p k s^{+}$E. coli strains induce double-strand DNA breaks, mutations, chromosomal rearrangements, and cell cycle arrest [19]. Accordingly, $p k s^{+}$E. coli strains induce single-base substitution/indels mutational patterns, which are predominantly detected in CRC patients [20]. In addition, the enterotoxigenic B. fragilis (ETBF), an anaerobic bacterium found in the human intestinal microbiota, produces an enterotoxin (B. fragilis toxin, BFT), which is highly associated with CRC [21], by activating $\beta$-catenin signaling as well as the secretion of interleukin (IL)-8 in colonic epithelial cells, leading to persistent cellular proliferation [22]. The alteration of the gut microbiota composition, known as "dysbiosis", has been observed in CRC patients [23]. A large body of literature has reported that fecal and intestinal mucosa samples from CRC patients display a lower bacterial diversity compared to healthy individuals [24,25]. In addition, CRC patients show significant alterations in specific bacterial taxa, with a potentially detrimental impact on mucosal immune responses [25]. In particular, the CRC-associated microbiota is characterized by the increased abundance of Enterobacteriaceae, Streptococcus, and typical genera belonging to the oral microbiota 
such as Fusobacterium, Gemella, Peptostreptococcus, Prevotella, Solobacterium, and Parvimonas [26-28]. On the contrary, the Firmicutes phylum (especially the Ruminococcaceae and Lachnospiraceae families) as well as Bifidobacterium, Odoribacter, and Streptococcus are substantially underrepresented in CRC patients $[29,30]$. In fact, gut microbiota transplant from CRC patients into mice is sufficient to disrupt the intestinal barrier, leading to low-grade inflammation and dysbiosis. Indeed, conventional and germ-free (GF) mice transplanted with stool samples from CRC patients developed high-grade dysplasia and macroscopic polyps concomitantly with a higher proportion of colonic Ki- 67 positive proliferating cells as well as increased expression of C-X-C motif chemokine receptor 1, C-X-C motif chemokine receptor 2, IL-17A, IL-22, and IL-23A cytokines. [31]. Similarly, Apc ${ }^{\mathrm{Min} /+}$ mice (carrying a mutation predisposing them to intestinal adenoma and tumor formation) transplanted with feces from CRC patients showed an increase in the number of intestinal tumors, downregulated expression of mucin-2, regenerating islet-derived protein and intestinal secretory immunoglobulin A, upregulation of the NLRP3 inflammasome, and increased production of pro-inflammatory cytokines IL-1 $\beta$ and tumor necrosis factor (TNF)- $\alpha$. The hyperproliferative and pro-inflammatory phenotype of the CRC associated-mucosa can be attributed to a dysbiotic microbiota, defined as an "imbalanced" gut microbial composition, associated with disease, that promotes the activation of the Wnt signaling pathway [32]. Indeed, alterations of the gut microbiota can also influence tumor development and progression by impairing immunosurveillance [33], leading to features of exhaustion once tumors are established [34], together with a pro-inflammatory phenotype at early stages [23,35-38]. Fusobacterium nucleatum $(F n)$ is commonly found in colorectal tissue with high-grade dysplasia as well as in adenomas. It has been shown that $F n$ modulates several immune responses towards CRC tumor progression, influencing the pre-tumoral environment [39], inducing the production of inflammatory mediators (IL-6, IL-8, IL-1 $\beta$ ) [40], transforming growth factor (TGF)- $\beta$ and TNF- $\alpha$ [41], and suppressing antitumor immunity by the secretion of Fap2, a natural killer inhibitory ligand [42]. Similarly to colibactin and BFT, Fn mediates DNA damage and promotes tumor cell proliferation through the $\mathrm{Wnt} / \beta$-catenin pathway [43]. Furthermore, bacterial metabolism might affect CRC progression by the production of oxidative stress molecules [30,44,45], promoting chronic inflammation and disrupting intestinal barrier integrity $[36,46]$. Moreover, choline degradation by gut bacteria contributes to colon cancer via the synthesis of trimethylamine N-oxide, a potential carcinogen [28].

\subsection{Anti-Oncogenic Effects of the Gut Microbiota in Colon Cancer}

On the other hand, many microbes within the gut microbiota have shown anticancer activities (Table 1). Some lines of evidence have shown that Lactobacillus, Bifidobacterium, and non-enterotoxigenic Bacteroides fragilis (NTBF) can control DNA damage by promoting epithelium renewal through lactic acid production, the modulation of the immune system by reducing the Th17 pool, enhancing major histocompatibility complex-II expression on dendritic cells, and improving natural killer cell and cytotoxic T cell recruitment and cytotoxicity [10,47-51]. Furthermore, the anticancer activities of the gut microbiota are also promoted by short chain fatty acid (SCFA) production. Indeed, one of the most prominent signatures of a healthy microbiota is the presence of SCFA-producing bacteria, such as members of the Lachnospiraceae and Ruminococcaceae families, among others [10,52]. SCFAs, by modulating histone deacetylase inhibitory activity, promote the accumulation and differentiation of Treg cells [53-55] controlling tumor progression. Accordingly, two anti-tumorigenic strains of the microbiota recently identified, Faecalibaculum rodentium and its human homologue, Holdemanella biformis, were able to control protein acetylation and tumor cell proliferation through the production of SCFAs, inhibiting the calcineurin and cytoplasmic 3 (NFATc3) activation pathway in mouse and human settings [56]. 
Table 1. Summary of bacteria known to be involved in colorectal cancer progression and prevention.

\begin{tabular}{|c|c|c|c|}
\hline Name & $\begin{array}{c}\text { (Potential) Role in CRC } \\
\text { Oncogenicity }\end{array}$ & Mechanism of Action & References \\
\hline $\begin{array}{l}\text { Proteobacteria, especially the } \\
\text { Enterobacteriaceae family }\end{array}$ & Pro-oncogenic & $\begin{array}{l}\text { Opportunistic pathogens, } \\
\text { promotion of inflammation }\end{array}$ & {$[22,37]$} \\
\hline Escherichia coli & Pro-oncogenic & $\begin{array}{l}\text { DNA damage by colibactin, } \\
\text { induction of a pro-inflammatory } \\
\text { environment }\end{array}$ & {$[18,19]$} \\
\hline $\begin{array}{l}\text { Enterotoxigenic Bacteroides } \\
\text { fragilis }(\mathrm{ETBF})\end{array}$ & Pro-oncogenic & $\begin{array}{l}\text { Colon cell hyperproliferation by } \\
\beta \text {-catenin pathway activation and } \\
\text { IL- } 8 \text { production }\end{array}$ & {$[20,21,50,57-59]$} \\
\hline Fusobacterium nucleatum & Pro-oncogenic & $\begin{array}{c}\text { Promotion of inflammation, } \\
\text { impairment of antitumor immunity, } \\
\text { activation of } \beta \text {-catenin pathway, } \\
\text { DNA damage }\end{array}$ & [39-42] \\
\hline Ruminococcaceae family & Anti-oncogenic & SCFA production & {$[9,51]$} \\
\hline Lachnospiraceae family & Anti-oncogenic & SCFA production & {$[9,51]$} \\
\hline Bifidobacteria & Anti-oncogenic & $\begin{array}{l}\text { SCFA production, reduction of } \\
\text { pro-inflammatory cytokines, } \\
\text { epithelial cell renewal }\end{array}$ & {$[9,45-47]$} \\
\hline $\begin{array}{l}\text { Lactobacilli, including L. casei, } \\
\text { L. plantarum, L. rhamnosus, } \\
\text { and L. acidophilus }\end{array}$ & Anti-oncogenic & $\begin{array}{l}\text { SCFA production, reduction of } \\
\text { pro-inflammatory cytokines, } \\
\text { enhancement of antitumor } \\
\text { immunity, epithelial cell renewal }\end{array}$ & {$[46,47,50]$} \\
\hline $\begin{array}{c}\text { Non-enterotoxigenic } \\
\text { Bacteroides fragilis (NTBF) }\end{array}$ & Anti-oncogenic & $\begin{array}{l}\text { Boost of antitumor immunity, } \\
\text { amelioration of inflammation by } \\
\text { PSA production }\end{array}$ & {$[48,50]$} \\
\hline $\begin{array}{l}\text { Faecalibaculum rodentium and } \\
\text { Holdemanella biformis }\end{array}$ & Anti-oncogenic & SCFA production & [55] \\
\hline Akkermansia muciniphila & Anti-oncogenic & $\begin{array}{l}\text { SCFA production, regulation of } \\
\text { intestinal barrier integrity }\end{array}$ & {$[9,60,61]$} \\
\hline Enterococcus faecalis & Anti-oncogenic & $\begin{array}{l}\text { Improvement of intestinal } \\
\text { inflammation }\end{array}$ & [62] \\
\hline
\end{tabular}

\section{Lifestyle, Diet, and Microbiota in the Early Onset of CRC}

Early-onset colorectal cancer (EOCRC) is the second most common cancer and the third leading cause of cancer mortality in people $<50$ years of age in the USA. The incidence of EOCRC has been on the rise over the past four decades and it is expected to increase by $>140 \%$ by 2030 . At present, different established cancer drivers have been linked to EOCRC including diet, sedentary lifestyle, smoking, and alcohol [63]. The gut microbiota is probably at the intersection of these risk factors and EOCRC. Indeed, the gut microbiome and inflammation are key players and master regulators of CRC onset and progression, as discussed above. The World Cancer Research Foundation (London, UK) and the American Institute for Cancer Research (Washington, DC, USA) consider diet to be one of the most important exogenous factors in CRC etiology [64]. The use of dietary modifications to supplement conventional cancer therapy is, therefore, a practical approach that is receiving growing attention. Dietary composition also dictates nutrient availability in the TME. Manipulation of the metabolic environment of cancer cells markedly changes their metabolic activity, producing shifts in drug sensitivity, proliferation rate, and metabolic requirements. The diet also influences the composition of the gut microbiota and, thus, the effect that gut microbes exert on the above-mentioned mechanisms.

It is now widely recognized that the adoption of a westernized diet rich in red meat and saturated fat and low in fiber exerts a negative effect on intestinal homeostasis [65], also promoting gut dysbiosis and inflammation [50,66-70]. The putative indication of colon cancer risk and a high-fat, low-fiber western diet was evaluated in a two-week diet exchange study among rural Africans, who usually have a low-fat, high-fiber diet, and African Americans, who usually consume the western diet. The diet exchange resulted in remarkable reciprocal changes in microbiota composition, as demonstrated by 
a shift in African Americans fed with the high fiber diet from Bacteroides and butyrate-producing bacteria (e.g., Roseburia intestinalis and Clostridium symbiosum) towards stronger co-occurrence patterns, including Firmicutes, which are typically associated with complex carbohydrate fermentation. On the other hand, the low-fiber/high-fat intervention was associated with an increase in F. nucleatum. Moreover, the latter were characterized by an increase in proliferative and inflammatory markers such as Ki67 and cluster of differentiation (CD) $3^{+}$intraepithelial lymphocytes and $\mathrm{CD} 68^{+}$lamina propria macrophages [71]. It has been postulated that the higher risk of developing CRC through a high-fat diet (HFD) may be due to an increase in the intestinal secretion of primary bile acids, converted into secondary bile acids by the gut microbiota, such as deoxycholic acid and lithocholic acid, which have been associated with a great increase in intestinal tumor formation and inflammatory damage in mice [72].

Changes not only in the diet but also in the use of food additives (used to extend the shelf-life of processed foods) have resulted in a considerable shift in food quality and increased risk of CRC onset. It is well known that nitrite and nitrate consumption, rich in processed meats, can lead to the formation of N-nitroso compounds by gut microbes, some of which are carcinogenic [73]. The health and regulatory issues related to the addition of food ingredients are too vast to cover in this review and have been covered elsewhere [74]; nevertheless, it is worthwhile to consider a few examples of food additives that modulate the gut microbiome and the host inflammatory status, factors associated with CRC development [73]. Monosodium glutamate is an additive used to enhance the flavor of savory foods able to induce obesity and diabetes. Interestingly, monosodium glutamate increases the susceptibility to CRC in models of inflammation-induced colorectal carcinogenesis [75]. Additionally, the food additive titanium dioxide, commonly used as a whitening and brightening agent, promotes colon inflammation and neoplastic lesions in chemically-induced carcinogenesis models [76,77]. Relatively low concentrations of two commonly used emulsifiers, carboxymethylcellulose and polysorbate-80, altered the gut microbiota composition and promoted low-grade intestinal inflammation in animal models $[78,79]$. These data suggest a role of food additives in the incidence of CRC development in humans. Altogether, these studies support a mechanistic link between the gut microbiota and CRC, since external factors that modulate the gut microbiome include not only stress and dietary factors but also elements previously thought to be disconnected from colon health, such as birth mode, breastfeeding behaviors, and maternal stress and nutrition [80-82].

\section{Relevance of the Gut Microbiota in the Efficiency of Cancer Therapies}

Advancements in CRC pathophysiological understanding have increased the array of treatment options for local and advanced disease, leading to individual therapeutic plans. Surgery is the cornerstone of curative treatment for patients with non-metastasized CRC [83]. In more advanced cases, neoadjuvant treatments, including preoperative chemotherapy, chemoradiotherapy, or radiotherapy, can reduce tumor load and stage and might be necessary to optimize the chances of a successful resection [84]. Current chemotherapies include both single-agent therapy, which is mainly fluoropyrimidine (5-FU)-based, and multiple agent regimens containing oxaliplatin (OX), irinotecan (IRI) and capecitabine (CAP or XELODA or XEL) [85]. Radical surgery and various chemotherapeutic agents can perceptibly create a state of dysbiosis, further exaggerating the influence of deleterious bacteria, reducing efficacy, and exacerbating the toxicity of chemotherapy [86]. In particular, compared with preoperative samples, fecal samples collected postoperatively exhibit a significant decrease in obligate anaerobes, tumor-related bacteria, and butyric acid-producing bacteria. However, a relevant increase in some conditional pathogens, such as Bilophila, Eggerthella, and Anaerostipes, was observed [87]. Moreover, chemotherapy also alters the intestinal microbiota through the so called "rebound effect", which is characterized by a dramatic increase in pathogens and a shift in lactate-utilizing bacteria from Veillonella to Butyricimonas and Butyricicoccus, as well as a decrease in commensals [87]. Accordingly, stool samples from resected stage III CRC patients characterized by CapeOX chemotherapy-induced diarrhea presented lower bacterial community richness and diversity, with Klebsiella pneumoniae being 
the most predominant microbial species [88]. Specific members of the gut microbiota have been found to play a vital role in chemoresistance to 5-FU and OX therapy by mediating autophagy [89]. Indeed, the potential relationship between $F n$ infection and the chemotherapeutic efficacy of 5-FU was investigated both in vitro and in vivo. F. nucleatum load reduced the chemosensitivity of CRC cells to 5-FU by targeting MYD88 innate immune signaling and specific microRNAs responsible for the activation of the autophagy pathway. All these results demonstrate how $F n$ abundance is well correlated with a lower response in advanced CRC patients to 5-FU-based adjuvant chemotherapy after radical surgery $[89,90]$. In addition, other gut microbes might aggravate chemotherapy-related adverse reactions via the microbial metabolism of chemotherapy agents [91,92]. For instance, IRI effectiveness is severely limited by gastrointestinal tract toxicity caused by gut bacterial $\beta$-glucuronidase enzymes [91,93].

Besides these canonical treatments, other therapies have been explored for CRC management. Targeted therapies include four main groups of drugs: monoclonal antibodies against epidermal growth factor receptor (EGFR) (cetuximab and panitumumab), monoclonal antibodies against vascular endothelial growth factor (VEGF)-A (bevacizumab), fusion proteins that target multiple proangiogenic growth factors (e.g., aflibercept), and small-molecule-based multikinase inhibitors (e.g., regorafenib) [84]. These treatments can work on cancerous cells by directly inhibiting cell proliferation, differentiation, and migration, but they can also alter the TME to slow down tumor growth and promote a stronger immunosurveillance response [85]. Immune escape has been frequently identified in various cancers, including CRC [94]. One major explanation is tumor-related T cell inactivation and exhaustion via activation of co-inhibitory receptors, the so-called immune checkpoint receptors, on the surface of $\mathrm{T}$ cells [60], which include programmed cell death protein (PD)-1 and cytotoxic T lymphocyte antigen 4 (CTLA-4). Checkpoint inhibitors are now a standard of care in microsatellite-instable CRC patients $[61,95,96]$. The gut microbiota is an important player affecting the efficacy of the immune checkpoint blockade [97]. Initial findings by Vetizou et al. showed that the CTLA-4-targeting antibody ipilimumab could treat specific-pathogen-free mice but not GF mice. In addition, antibiotics including ampicillin, colistin, and streptomycin compromise the antitumor effects of this antibody, indicating the key role of the gut microbiota in immunotherapy outcomes [98]. Ipilimumab induces significant changes in the microbiome-in particular, a decrease in the bacterial orders Bacteroidales and Burkholderiales. Similarly, the presence of Bifidobacterium was positively correlated with anti-tumor T-cell responses in melanoma and bladder cancer mouse models treated with an anti-PD-L1 agent [99]. Gut microbes also affect the capacity of cytotoxic T cells to infiltrate the TME. Gut colonization with different Bacteroidales and non-Bacteroidales strains enhanced the efficacy of PD-1 and CTLA-4 monoclonal antibody therapies in GF mice due to the stronger immune-protective infiltration of $\mathrm{CD}^{+} \mathrm{T}$ cells. Unfortunately, the adverse effects of immunotherapy are dominated by autoimmune complications, such as fatal forms of colitis, as seen in metastatic melanoma of Ipilimumab-treated patients, which developed intestinal inflammation within the first 16 weeks of treatment [100].

\section{Clinical Applications of the Gut Microbiota Modulation for CRC Prevention and Management}

Several approaches, among which dietary interventions, antibiotic treatments, probiotics, prebiotics, and postbiotics, as well as fecal microbiota transplantation (FMT), have been explored to target and modulate gut microbiota composition, including both microbial physiology and/or their metabolites that cause or contribute to CRC directly or indirectly (Figure 1). Various experimental studies have deepened the understanding of the role of gut biomodulators and microbe-based treatments as antineoplastic agents, although a practical clinical application in CRC prevention and management is still largely lacking. 


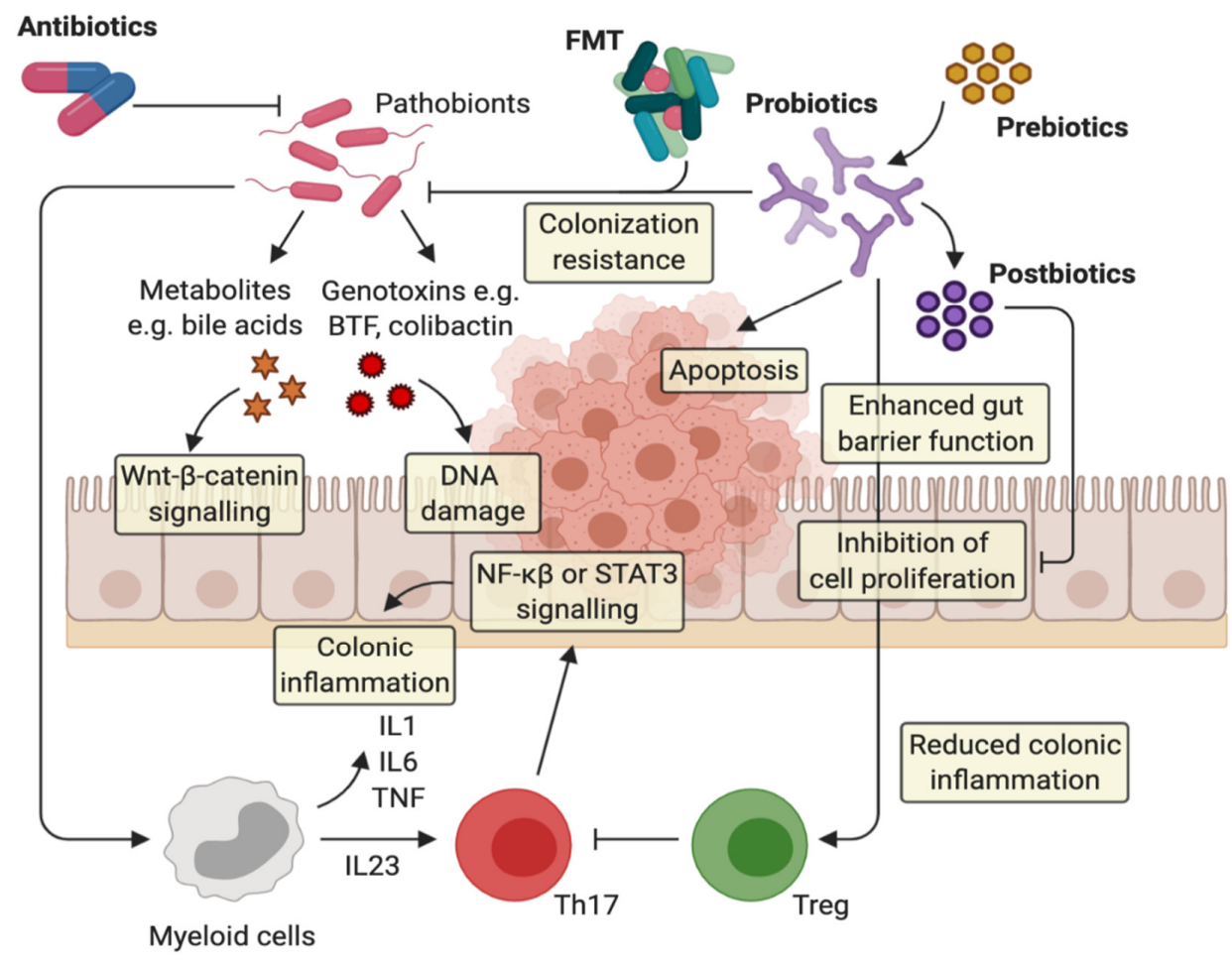

Figure 1. The gut microbiota can influence colorectal carcinogenesis via a variety of mechanisms, including microbial-derived factors such as metabolites or genotoxins. Skewed host-microbe interactions contribute to the activation of pro-carcinogenic inflammatory pathways that ultimately lead to the progression of CRC. Antibiotics usage is effective in eradicating pathobionts, but its non-selective antimicrobial actions can affect gut homeostasis by also killing health-promoting bacteria and, therefore, reducing its application in CRC management. Prebiotic function fosters probiotic growth. Probiotics act through different anticancerogenic mechanisms: (i) probiotics can inhibit the colonization of pathogenic bacteria, (ii) they can enhance barrier function increasing mucin production and tight junction protein expression, (iii) they promote homeostatic immune responses, contributing to the expansion of anti-inflammatory responses by Treg cells and the modulation of pro-inflammatory cytokine release, (iv) they promote apoptosis on cancer cells. Postbiotics induce selective cytotoxicity against tumor cells as well as the control of tumor cell proliferation by inhibiting NFATc3 activation. Finally, fecal microbiota transplantation (FMT) could be used in CRC management to restore microbiome normobiosis and therefore induce homeostatic immune responses; nevertheless, potential complications associated with FMT include the risk of introducing new pathobionts and the spreading of disease-associated genes.

\subsection{Dietary Interventions}

As mentioned above, diet plays a significant role in shaping the microbiome and, therefore, in the management of CRC. While the impact of a westernized high-fat diet on CRC and on the gut microbiota has been well characterized, the protective effects of grain diets, known to be associated with low CRC risk, remain uncertain at the microbiota level. Yang et al. assessed the capacity of seven different grains to reduce CRC risk in mice fed with an HFD, showing that the consumption of non-glutinous rice, glutinous rice, and sorghum led to the highest reduction in CRC risk. In particular, non-glutinous rice stabilized key altered genera associated with CRC, including Bacteroides, Lactobacillus, Ruminococcus, and Acinetobacter [101]. Moreover, through a prospective cohort study, a diet rich in whole grains and dietary fiber was associated with a lower risk of developing $F$. nucleatum-positive CRC but not $F$. nucleatum-negative CRC, supporting a potential role of intestinal microbiota in the development of CRC [102]. Vitamin D supplementation reduces cancer incidence in mouse models of bacteria-driven colitis and CRC [57]. Azoxymethane/dextran sodium sulfate (AOM/DSS)-induced CRC mice fed with high doses of vitamin D showed not only improved body weight gain and less colon shortening but 
also a lower expression of inflammatory cytokines such as IL-6 and TNF- $\alpha$. Vitamin D has also a significant regulatory effect on the homeostasis of the microbiota, especially on the regulation of the intestinal barrier integrity mediated by Akkermansia muciniphila, a mucin-utilizing bacterium [58,59].

Since there are no clear guidelines on the type of nutrition that could have a major impact on cancer incidence, various forms of reduced caloric intake, such as fasting, demonstrate a wide range of beneficial effects in preventing malignancies and increasing the efficacy of cancer therapies [103]. One of the main mechanisms through which fasting induces metabolic improvements is certainly mediated by the gut microbiota. For instance, every-other-day fasting led to an alteration of the gut microbiota composition, elevating fermentation products like acetate and lactate. Moreover, this dietary regimen enriched the levels of Firmicutes and also the production of SCFAs, decreasing Bacteroidetes, Actinobacteria, and Tenericutes [104]. In particular, food withdrawal decreased the abundance of potentially pathogenic Proteobacteria while elevating A. muciniphila in mice fed with HFD [105]. Due to various deficiencies in one or both key mitochondrial enzymes, tumors are not able to metabolize ketone bodies as an energetic source. Thus, the administration of a ketogenic diet (KD) may be a reasonable therapeutic strategy to inhibit tumor growth [106]. KDs are low-carbohydrate, high-fat diets, mimicking the metabolic state of fasting by inducing a physiological rise in acetoacetate and beta-hydroxybutyrate [107]. For cancer prevention, a high intake of mono-unsaturated fatty acids and n-3 polyunsaturated fatty acids could be hypothesized to be beneficial for promoting gut health [108], as demonstrated by the delayed tumor growth induced by a KD rich in omega-3 fatty acids in a CRC mouse xenograft model [106]. Lastly, supplementation with $\alpha$-ketoglutarate, an important intermediary in the nuclear factor kappa light chain enhancer of activated B cells (NF-kB)-mediated inflammatory pathway, offered significant protection against CRC development in mice. Thus, $\alpha$-ketoglutarate not only exhibited immunomodulatory effects mediated via the downregulation of IL-6, IL-22, TNF- $\alpha$, and IL-1 $\beta$ cytokines but also minimized the frequency of opportunistic pathogens (Escherichia and Enterococcus), while it increased the populations of Akkermansia, Butyricicoccus, Clostridium, and Ruminococcus, suggesting that dietary $\alpha$-ketoglutarate intervention may protect against inflammation-related CRC [109].

\subsection{Antibiotics}

Modulation of the gut microbiota through the use of antibiotics was partially evaluated in CRC, with only few studies present in the literature [110]. Cefoxitin, a semi-synthetic and broad-spectrum cephalosporin, induced a complete and durable clearance of enterotoxigenic B. fragilis colonization in previously ETBF-inoculated mice, with a concomitant decrease in median adenoma formation [111]. Consistent with the pro-tumorigenic Th17 immune response of ETBF [112,113], its eradication was accompanied by an abrupt reduction in colonic IL-17A levels, suggesting that other microbes are implicated in the IL-17 response [111]. Erythromycin has the ability to suppress the transcriptional activity of NF- $\mathrm{KB}$ and the activator protein-1 (AP-1), as well as its downstream targets, IL-6 and cyclooxygenase-2 (COX-2), in human CRC cells. Moreover, a reduction in Il-6 and cox-2 mRNA expression was also observed in $\mathrm{Apc}^{\mathrm{Min} /+}$ mice, in which the number of intestinal polyps was reduced as well [114]. Berberine (BBR), an isoquinoline molecule with antibacterial activity [115], has been used to treat F. nucleatum colonization in Apc ${ }^{\mathrm{Min} /+}$ mouse models. BBR not only was able to reverse the microbiota imbalance induced by $F n$ but also blocked the secretion of mucosal immune factors, such as IL-21, IL-22, IL-31, and CD40L. In addition, this compound inhibited the Fn-induced activation of the Janus kinase/signal transducer and activator of transcription (JAK/STAT) and mitogen-activated protein kinase/extracellular signal-regulated kinases (MAPK/ERK) pathway [116]. Moreover, the microbial structure alteration, characterized by the increase in Tenericutes and Verrucomicrobia, was dramatically reversed in $F n$-infected mice after BBR intervention, suggesting an antimicrobial intervention as a potential treatment for patients with $F n$-associated CRC [117]. Metronidazole has also been explored as an alternative to treat $F$. nucleatum colonization. This antibiotic reduced the $F n$ load, cancer cell proliferation, and overall tumor growth in mice bearing colon cancer xenografts [117]. However, antibiotic administration, being the most aggressive means of manipulating gut microbiota composition, 
has been controversial in its role in cancer management. Although gut microbiome depletion was shown to inhibit cancer progression, accumulating lines of evidence highlight how antibiotics can compromise immunotherapy efficacy or induce disease progression by creating further microbial dysbiosis [118,119].

\subsection{Probiotics}

For CRC prevention and management, another potential strategy is represented by probiotics. Probiotics are living microorganisms which can confer positive effects on health by impacting on the resident microbiota, intestinal epithelium cells, and, globally, the immune system [120]. Nowadays, several bacterial species are used as probiotics, which are commercially available (Table 2).

Table 2. Examples of some commercially available probiotics.

\begin{tabular}{ccc}
\hline Brand Name & Strain & Producer \\
\hline Dicoflor & Lactobacillus rhamnosus GG & AGPHARMA \\
\hline Enterogermina & Bacillus clausii & SANOFI \\
\hline Enterolactis & Lactobacillus casei & SOFAR \\
\hline Nutriflor & Lactobacillus acidophilus DDS-1 & \\
& Lactobacillus bulgaricus DDS-14 & NUTRIGEA \\
& Bifidobacterium bifidum & \\
& Lactobacillus rhamnosus & \\
Probactiol Duo & Lactobacillus acidophilus NCFM & METAGENETICS \\
& Lactobacillus paracasei Lpc-37 & \\
& Bifidobacterium lactis Bi-07 & \\
& Bifidobacterium lactis Bi-04 & \\
& Streptococcus thermophilus & \\
& Bifidobacterium breve & \\
& Bifidobacterium longum & \\
& Bifidobacterium infantis & \\
VSL\#3 & Lactobacillus acidophilus & \\
& Lactobacillus plantarum & Lactobacillus paracasei \\
& Lactobacillus delbrueckii subsp. bulgaricus & \\
\hline Yakult & Lactobacillus casei Shirota & \\
\hline
\end{tabular}

Among them, lactic acid bacteria are the most frequently used, not only for their ability to contribute to colonization resistance [121] but also for their immunomodulatory effects [122]. Specific bacterial strains are able to prevent tumor development through the modulation of the immune system in CRC murine models. Oral treatment with Lactobacillus casei BL23, a probiotic strain well known for its anti-inflammatory [123] and anticancer properties [124], significantly protected mice against CRC development. In addition, this probiotic showed not only immunomodulatory effects by downregulating colonic IL-22 but also an antiproliferative effect mediated by the upregulation of caspase (casp)-7, casp-9, and Bik, as well as a decrease in Ki67 expression [125]. Probiotics have also been recently exploited to counteract chemotherapy-dependent dysbiosis, mucositis (inflammatory lesions of the oral and/or gastrointestinal tract caused by high-dose cancer therapies), post-surgical microbiota intestinal alterations, and relapses in CRC patients. Preclinical studies revealed that L. rhamnosus (Lcr35) reduces the severity of diarrhea and intestinal mucositis caused by adjuvant 5-FU-based chemotherapy in mice injected with CT26 colorectal adenocarcinoma cells. Moreover, Lcr35 treatment normalized the increased number of BCL2-associated X protein apoptotic and NF- $\mathrm{KB}$-activated cells as well as the upregulated expression of TNF- $\alpha$ and IL-6 [126]. A recent randomized, double-blind, placebo-controlled trial (NCT03782428) revealed that treatment with six viable microorganisms of Lactobacillus and Bifidobacterium strains significantly reduced the levels of pro-inflammatory cytokines 
such as TNF- $\alpha$, IL-6, IL-10, IL-12, IL-17A, IL-17C, and IL-22 and prevented post-surgical complications as well [127]. Probiotics are generally considered safe and well-tolerated for healthy subjects, but in patients with underlying medical conditions, their safety profile is uncertain [62]. Probiotic translocation, which refers to the entry of viable bacteria into extraintestinal sites, leads to the ensuing systemic or localized infections. Indeed, various case reports of probiotic-associated bacteremia, endocarditis, liver abscess, and pneumonia have been published [128]. Nevertheless, another theoretical risk regarding long-term probiotic use is the possible transmission of antibiotic-resistant genes via horizontal gene transfer [62].

\subsection{Prebiotics}

Prebiotics are non-digestible dietary compounds that stimulate the growth and activity of probiotics, conferring a competitive advantage to commensal bacteria capable of metabolizing these substrates or by increasing the production of beneficial metabolic products, such SCFAs, that result from their fermentation $[129,130]$. The health benefits of prebiotics goes beyond nutrition and they are gaining popularity among people (Table 3). However, great care must be taken to ensure their therapeutic efficacy, especially regarding intestinal tumors. The chemopreventive effect of galacto-oligosaccharides derived from lactulose revealed a remarkable reduction in colonic tumor numbers in a CRC animal model. Moreover, a significant decrease in pro-inflammatory bacteria was observed, as well as a substantial increase in beneficial populations such as Bifidobacterium [131]. Similarly, ginsenoside-Rb3 and ginsenoside-Rd effectively reduced the size and the number of the polyps and reinstated the dysbiotic gut microbial composition and intestinal microenvironment in $\mathrm{Apc}^{\mathrm{Min} /+}$ mice by promoting the growth of SCFA-producing bacteria [132]. Given the encouraging results obtained from studies conducted both in vitro and in vivo, prebiotic administration has also been evaluated in more structured, randomized clinical trials involving CRC patients. A randomized, double-blind, no-treatment parallel control clinical trial involving 140 perioperative CRC patients was performed to investigate the effects of prebiotics containing fructooligosaccharides, xylooligosaccharides, polydextrose, and resistant dextrin on the immune system and the intestinal microbiota. In the preoperative interval, prebiotics upregulated serum levels of $\operatorname{IgG}$, IgM, and transferrin, while in the postoperative period, they enhanced levels of IgG, IgA, CD8+ T cells, and total B lymphocytes. Prebiotic administration increased the abundance of Bifidobacterium and Enterococcus but decreased the abundance of Bacteroides in the preoperative timeframe. On the other hand, in the postoperative period, the abundance of Bacteroides was decreased, while Escherichia-Shigella was increased, suggesting that prebiotic intake is recommended to improve serum immunologic indicators in patients with CRC 7 days before operation, since surgical trauma can alter the gut microbiome [133]. However, recent studies have demonstrated that prebiotic interventions may exert variable effects in different individuals, probably due to differences in the host genetic background, which may plausibly explain the different tumor phenotype, oncogenic pathways, and, subsequently, the response to a specific intervention [134].

Table 3. Prebiotic-rich foods and their effects on human health.

\begin{tabular}{cccc}
\hline Prebiotic & Origin & Clinical Benefit & References \\
\hline $\begin{array}{c}\text { Fructo-Oligosaccharides } \\
\text { (FOS) }\end{array}$ & $\begin{array}{c}\text { Vegetables, cereals } \\
\text { (onion, garlic, artichokes) }\end{array}$ & $\begin{array}{c}\text { Crohn's disease } \\
\text { Colitis } \\
\text { CRC } \\
\text { Obesity }\end{array}$ & {$[135]$} \\
\hline $\begin{array}{c}\text { Gluco-Oligosaccharides } \\
\text { (GOS) }\end{array}$ & $\begin{array}{c}\text { Legumes (lentils, chickpeas and } \\
\text { broad beans) }\end{array}$ & $\begin{array}{c}\text { Crohn's disease } \\
\text { Colitis } \\
\text { Obesity }\end{array}$ & {$[135,136]$} \\
\hline
\end{tabular}


Table 3. Cont.

\begin{tabular}{cccc}
\hline Prebiotic & Origin & Clinical Benefit & References \\
\hline \multirow{2}{*}{ Ginsenoside-Rb3 } & Panax Ginseng & Myeloid leukemia & CRC \\
& & Heart failure & {$[132,137]$} \\
& & Crohn's disease \\
Colitis & \\
Inulin & CRC & {$[138]$} \\
& Asparagus and artichokes & Obesity & \\
& & Diabetes & \\
\hline Lactulose & Boiled milk & Constipation & {$[139]$} \\
\hline
\end{tabular}

\subsection{Postbiotics}

Postbiotics are chemical compounds of microbial origin including short chain fatty acids, enzymes, peptides, teichoic acids, peptidoglycan-derived muropeptides, endo- and exo-polysaccharides, cell surface proteins, vitamins, plasmalogens, and organic acids [140]. The chemopreventive effects of acetate, butyrate, and propionate mixture were evaluated in AOM/DSS-treated mice, determining a significant reduction in tumor incidence and size. Moreover, SCFAs suppressed pro-inflammatory cytokine expression, including that of IL-6, TNF- $\alpha$, and IL-17, as well as COX-2 and NF-kB [141]. The prophylactic effects of postbiotics were also shown by the oral intake of mitochonic acid 35, an indole compound, which ameliorated the disease activity index score and survival rate, reducing the macroscopic formation of colonic tumors in murine models of CRC. In addition, it was able to downregulate colonic TNF- $\alpha$, IL-6, TGF- $\beta 1$, and fibronectin 1 expression, suggesting its ability to inhibit CRC carcinogenesis [142]. Among the non-viable microbial cells, researchers have exploited the possible therapeutic effects of Enterococcus faecalis. In this regard, it was observed that pre-treatment of THP-1-derived macrophages with heat-killed E. faecalis inhibited NLRP3 inflammasome activation in response to fecal content or commensal microbes, Proteus mirabilis or E. coli, according to the reduction in casp-1 activation and IL-1 $\beta$ maturation. Moreover, experiments in vivo showed that E. faecalis improved the severity of intestinal inflammation, protecting mice from the formation of colon tumors [143]. Interestingly, postbiotics have also been evaluated as adjuvants of anti-cancer therapies. The combined efficacy of L. acidophilus cell lysates with an anti-CTLA-4 monoclonal antibody was tested in vivo. In contrast to anti-CTLA-4 monotherapy, L. acidophilus lysates attenuated body weight loss and the combined administration significantly protected mice against CRC development, suggesting an enhancement of anti-CTLA-4 antitumor activity. Moreover, the synergistic combination led to an increase in CD8+T cells, especially the effector memory T cells, a decrease in Tregs, and it alternatively activated macrophages (M2) in the TME. Additionally, pre-treatment with L. acidophilus lysate in vitro showed an immunomodulatory effect through the inhibition of M2 polarization and of IL-10 production by lipopolysaccharide-activated macrophages. Lastly, the combined administration significantly inhibited the abnormal increase in the relative abundance of Proteobacteria and partly counterbalanced CRC-induced dysbiosis in mice. Thus, CTLA-4 blocking antibodies in combination with the present lysates may be of importance for the development of new therapeutic strategies against CRC to be tested in clinical trials [144]. The postbiotic field is as yet a highly unknown area, considering that the number and diversity of bacterial metabolites are vast. Thus, their safety profile is still under preclinical and clinical evaluation [62].

\subsection{FMT}

Fecal microbiota transplantation (FMT) - i.e., the transfer of a microbial ecology from a healthy donor into a patient-is currently being explored as a therapeutic strategy to restore normobiosis, the normal state of the human intestinal microbiota, in different pathological contexts [145]. Since CRC is characterized by a status of dysbiosis, FMT is considered as a potential clinical application in patients. To date, FMT has only proved to be highly successful in treating recurrent and antibiotic refractory 
Clostridiodes difficile (C. difficile) infection, with cure rates of approximately 90\% [129]. In a CRC mouse model, FMT was able to normalize the gut microbiota through the reduction of tumor growth. FMT contributed to reducing the levels of inflammation by decreasing IL-1 $\beta$, IL- 6 , and TNF- $\alpha$ levels and increasing anti-inflammatory cytokines such as IL-10 and TGF- $\beta$ through the inhibition of canonical NF- $\mathrm{kB}$ activity and cellular proliferation. Moreover, FMT treatment triggered the accumulation of Tregs but not Th1, Th2, and Th17 cells [146]. Additionally, the chemopreventive potential of FMT on FOLFOX-induced mucosal injury was evaluated. Microbiota transplantation reduced the severity of diarrhea and intestinal mucositis, suppressed IL-6 levels, and restored the number of goblet cells, zonula occludens-1, apoptotic, and NF-KB-positive cells, as well as the expression of toll-like receptors and MYD88. All these beneficial effects were accompanied by a restoration of the gut microbiota composition without causing bacteremia [147]. However, it is worth noting that the impact of FMT on the recipient immune system is complicated and unpredictable, and the risk of dissemination of unknown pathogens cannot be prevented. In addition, numerous questions remain to be answered, including the features that a "good donor" should present, the routes of administration, and the long-term effects of this therapy [148].

\section{Conclusions and Perspective}

The core of CRC carcinogenesis is also defined by gut microbiota metabolic activity and a dysbiotic composition. Hence, a consortium of inflammatory responses, virulence factors, and impaired epithelial signaling create a suitable microenvironment for the development of disrupted and irregular interactions between the host and the gut microbiota [149]. Even if surgery is the primary therapeutic option, patients with advanced disease or cancer recurrence after surgery remain difficult to cure. Since the gut microbiota is gaining more attention, a deeper knowledge of its interaction with the host's immune system will elucidate the outcomes of cancer therapeutic strategies. Lastly, research is currently assessing the impact of personalized diets and biomodulators to restore a eubiotic condition for the prevention and treatment of CRC $[150,151]$.

Author Contributions: Writing—original draft preparation C.A., F.P.; writing—review and editing F.S., M.R.G., A.D.-B., G.L., F.F.; supervision F.S., F.F.; funding acquisition F.F. All authors have read and agreed to the published version of the manuscript.

Funding: This work was made possible through a grant from AIRC, Associazione Italiana per la Ricerca sul Cancro, to FF (IG-2019 22923).

Conflicts of Interest: The authors declare no conflict of interest. The funders had no role in the design of the study; in the collection, analyses, or interpretation of data; in the writing of the manuscript, or in the decision to publish the results.

$\begin{array}{ll}\text { Abbreviations } & \\ \text { Adenomatous polyposis coli } & \text { APC } \\ \text { Azoxymethane/dextran sodium sulfate } & \text { AOM/ASS } \\ \text { B. fragilis toxin } & \text { BFT } \\ \text { Berberine } & \text { BBR } \\ \text { Calcineurin and cytoplasmic } 3 & \text { Nfatc3 } \\ \text { Capecitabine } & \text { CAP or XELODA or XEL } \\ \text { Capecitabine oxaliplatin } & \text { CAPeOX } \\ \text { Caspase } & \text { casp } \\ \text { Cluster of differentiation } & \text { CD } \\ \text { Colorectal cancer } & \text { CRC } \\ \text { Cyclooxygenase-2 } & \text { COX-2 } \\ \text { Cytotoxic T lymphocyte antigen } 4 & \text { CTLA-4 } \\ \text { Early-onset colorectal cancer } & \text { EOCRC } \\ \text { Enterotoxigenic } B \text {. fragilis } & \text { ETBF }\end{array}$


Epidermal growth factor receptor $\quad$ EGFR

Fecal microbiota transplantation $\quad$ FMT

Fluorouracile 5-FU

Fusobacterium nucleatum $\quad$ Fn

Germ-free GF

High fat diet $\quad$ HFD

Interleukin $\quad$ IL

Irinotecan

Janus kinase/signal transducer and activator of transcription JAK/STAT

Ketogenic diet $\quad$ KD

Mitogen-activated protein kinase/extracellular signal-regulated kinases MAPK/ERK

Non-enterotoxigenic Bacteroides fragilis $\quad$ NTBF

Nuclear factor kappa light chain enhancer of activated B cells $\quad$ NF- $\mathrm{kB}$

Oxaliplatin OX

Programmed cell death protein $\quad$ PD-1

Short chain fatty acids SCFAs

Transforming growth factor TGF

Tumor microenvironment TME

Tumor necrosis factor $\quad$ TNF

Vascular endothelial growth factor $\quad$ VEGF

\section{References}

1. Bray, F.; Ferlay, J.; Soerjomataram, I.; Siegel, R.L.; Torre, L.A.; Jemal, A. Global cancer statistics 2018: GLOBOCAN estimates of incidence and mortality worldwide for 36 cancers in 185 countries. CA Cancer J. Clin. 2018. [CrossRef]

2. Heavey, P.M.; McKenna, D.; Rowland, I.R. Colorectal cancer and the relationship between genes and the environment. Nutr. Cancer 2004, 48, 124-141. [CrossRef] [PubMed]

3. Sánchez-Alcoholado, L.; Ramos-Molina, B.; Otero, A.; Laborda-Illanes, A.; Ordóñez, R.; Medina, J.A.; Gómez-Millán, J.; Queipo-Ortuño, M.I. The role of the gut microbiome in colorectal cancer development and therapy response. Cancers 2020, 12, 1406. [CrossRef] [PubMed]

4. Grady, W.M.; Markowitz, S.D. The Molecular Pathogenesis of Colorectal Cancer and Its Potential Application to Colorectal Cancer Screening. Dig. Dis. Sci. 2015. [CrossRef]

5. Schatoff, E.M.; Leach, B.I.; Dow, L.E. WNT Signaling and Colorectal Cancer. Curr. Colorectal Cancer Rep. 2017, 13, 101-110. [CrossRef] [PubMed]

6. Dow, L.E.; O’Rourke, K.P.; Simon, J.; Tschaharganeh, D.F.; Van Es, J.H.; Clevers, H.; Lowe, S.W. Apc Restoration Promotes Cellular Differentiation and Reestablishes Crypt Homeostasis in Colorectal Cancer. Cell 2015. [CrossRef]

7. Boland, C.R.; Thibodeau, S.N.; Hamilton, S.R.; Sidransky, D.; Eshleman, J.R.; Burt, R.W.; Meltzer, S.J.; Rodriguez-Bigas, M.A.; Fodde, R.; Ranzani, G.N.; et al. A National Cancer Institute workshop on microsatellite instability for cancer detection and familial predisposition: Development of international criteria for the determination of microsatellite instability in colorectal cancer. Cancer Res. 1998, 58, 5248-5257.

8. Dekker, E.; Tanis, P.J.; Vleugels, J.L.A.; Kasi, P.M.; Wallace, M.B. Colorectal cancer. Lancet 2019, 394, $1467-1480$. [CrossRef]

9. Villéger, R.; Lopès, A.; Veziant, J.; Gagnière, J.; Barnich, N.; Billard, E.; Boucher, D.; Bonnet, M. Microbial markers in colorectal cancer detection and/or prognosis. World J. Gastroenterol. 2018, 24, 2327-2347. [CrossRef]

10. Routy, B.; Gopalakrishnan, V.; Daillère, R.; Zitvogel, L.; Wargo, J.A.; Kroemer, G. The gut microbiota influences anticancer immunosurveillance and general health. Nat. Rev. Clin. Oncol. 2018, 15, 382-396. [CrossRef]

11. Fujimoto, H.; Saito, Y.; Ohuchida, K.; Kawakami, E.; Fujiki, S.; Watanabe, T.; Ono, R.; Kaneko, A.; Takagi, S.; Najima, Y.; et al. Deregulated Mucosal Immune Surveillance through Gut-Associated Regulatory T Cells and PD-1 + T Cells in Human Colorectal Cancer. J. Immunol. 2018. [CrossRef]

12. Richard, M.L.; Sokol, H. The gut mycobiota: Insights into analysis, environmental interactions and role in gastrointestinal diseases. Nat. Rev. Gastroenterol. Hepatol. 2019, 16, 331-345. [CrossRef] [PubMed] 
13. Bäckhed, F.; Ley, R.E.; Sonnenburg, J.L.; Peterson, D.A.; Gordon, J.I. Host-bacterial mutualism in the human intestine. Science 2005, 307, 1915-1920. [CrossRef] [PubMed]

14. Chung, H.; Pamp, S.J.; Hill, J.A.; Surana, N.K.; Edelman, S.M.; Troy, E.B.; Reading, N.C.; Villablanca, E.J.; Wang, S.; Mora, J.R.; et al. Gut immune maturation depends on colonization with a host-specific microbiota. Cell 2012. [CrossRef] [PubMed]

15. Wong, S.H.; Yu, J. Gut microbiota in colorectal cancer: Mechanisms of action and clinical applications. Nat. Rev. Gastroenterol. Hepatol. 2019, 13, 691-706. [CrossRef]

16. Fearon, E.R.; Vogelstein, B. A genetic model for colorectal tumorigenesis. Cell 1990, 61, 759-767. [CrossRef]

17. Li, S.; Konstantinov, S.R.; Smits, R.; Peppelenbosch, M.P. Bacterial Biofilms in Colorectal Cancer Initiation and Progression. Trends Mol. Med. 2017, 23, 18-30. [CrossRef]

18. Collins, D.; Hogan, A.M.; Winter, D.C. Microbial and viral pathogens in colorectal cancer. Lancet Oncol. 2011, 12, 504-512. [CrossRef]

19. Dalmasso, G.; Cougnoux, A.; Delmas, J.; Darfeuille-Michaud, A.; Bonnet, R. The bacterial genotoxin colibactin promotes colon tumor growth by modifying the tumor microenvironment. Gut Microbes 2015. [CrossRef]

20. Pleguezuelos-Manzano, C.; Puschhof, J.; Rosendahl Huber, A.; van Hoeck, A.; Wood, H.M.; Nomburg, J.; Gurjao, C.; Manders, F.; Dalmasso, G.; Stege, P.B.; et al. Mutational signature in colorectal cancer caused by genotoxic pks + E. coli. Nature 2020. [CrossRef]

21. Zamani, S.; Taslimi, R.; Sarabi, A.; Jasemi, S.; Sechi, L.A.; Feizabadi, M.M. Enterotoxigenic Bacteroides fragilis: A Possible Etiological Candidate for Bacterially-Induced Colorectal Precancerous and Cancerous Lesions. Front. Cell. Infect. Microbiol. 2020. [CrossRef] [PubMed]

22. Wu, S.; Morin, P.J.; Maouyo, D.; Sears, C.L. Bacteroides fragilis enterotoxin induces c-Myc expression and cellular proliferation. Gastroenterology 2003. [CrossRef] [PubMed]

23. Flemer, B.; Lynch, D.B.; Brown, J.M.R.; Jeffery, I.B.; Ryan, F.J.; Claesson, M.J.; O’Riordain, M.; Shanahan, F.; O'Toole, P.W. Tumour-associated and non-tumour-associated microbiota in colorectal cancer. Gut 2017, 66, 633-643. [CrossRef]

24. Chen, W.; Liu, F.; Ling, Z.; Tong, X.; Xiang, C. Human intestinal lumen and mucosa-associated microbiota in patients with colorectal cancer. PLoS ONE 2012. [CrossRef]

25. Saffarian, A.; Mulet, C.; Regnault, B.; Amiot, A.; Tran-Van-Nhieu, J.; Ravel, J.; Sobhani, I.; Sansonetti, P.J.; Pédron, T. Crypt- and mucosa-associated core microbiotas in humans and their alteration in colon cancer patients. MBio 2019. [CrossRef] [PubMed]

26. Wirbel, J.; Pyl, P.T.; Kartal, E.; Zych, K.; Kashani, A.; Milanese, A.; Fleck, J.S.; Voigt, A.Y.; Palleja, A.; Ponnudurai, R.; et al. Meta-analysis of fecal metagenomes reveals global microbial signatures that are specific for colorectal cancer. Nat. Med. 2019, 25, 679-689. [CrossRef] [PubMed]

27. Sheng, Q.S.; He, K.X.; Li, J.J.; Zhong, Z.F.; Wang, F.X.; Pan, L.L.; Lin, J.J. Comparison of gut microbiome in human colorectal cancer in paired tumor and adjacent normal tissues. Onco. Targets. Ther. 2020, 13, 635-646. [CrossRef]

28. Thomas, A.M.; Manghi, P.; Asnicar, F.; Pasolli, E.; Armanini, F.; Zolfo, M.; Beghini, F.; Manara, S.; Karcher, N.; Pozzi, C.; et al. Metagenomic analysis of colorectal cancer datasets identifies cross-cohort microbial diagnostic signatures and a link with choline degradation. Nat. Med. 2019, 25, 667-678. [CrossRef]

29. Shah, M.S.; DeSantis, T.; Yamal, J.M.; Weir, T.; Ryan, E.P.; Cope, J.L.; Hollister, E.B. Re-purposing 16s rRNA gene sequence data from within case paired tumor biopsy and tumor-adjacent biopsy or fecal samples to identify microbial markers for colorectal cancer. PLoS ONE 2018, 13, 1-21. [CrossRef]

30. Long, S.; Yang, Y.; Shen, C.; Wang, Y.; Deng, A.; Qin, Q.; Qiao, L. Metaproteomics characterizes human gut microbiome function in colorectal cancer. NPJ Biofilms Microbiomes 2020, 6. [CrossRef]

31. Wong, S.H.; Zhao, L.; Zhang, X.; Nakatsu, G.; Han, J.; Xu, W.; Xiao, X.; Kwong, T.N.Y.; Tsoi, H.; Wu, W.K.K.; et al. Gavage of Fecal Samples From Patients With Colorectal Cancer Promotes Intestinal Carcinogenesis in Germ-Free and Conventional Mice. Gastroenterology 2017. [CrossRef] [PubMed]

32. Li, L.; Li, X.; Zhong, W.; Yang, M.; Xu, M.; Sun, Y.; Ma, J.; Liu, T.; Song, X.; Dong, W.; et al. Gut microbiota from colorectal cancer patients enhances the progression of intestinal adenoma in Apcmin/+ mice. EBioMedicine 2019. [CrossRef]

33. Fridman, W.H.; Pagès, F.; Sautès-Fridman, C.; Galon, J. The immune contexture in human tumours: Impact on clinical outcome. Nat. Rev. Cancer 2012, 12, 298-306. [CrossRef] [PubMed] 
34. Yu, A.I.; Zhao, L.; Eaton, K.A.; Ho, S.; Chen, J.; Poe, S.; Becker, J.; Gonzalez, A.; McKinstry, D.; Hasso, M.; et al. Gut Microbiota Modulate CD8 T Cell Responses to Influence Colitis-Associated Tumorigenesis. Cell Rep. 2020, 31, 107471. [CrossRef] [PubMed]

35. Mori, G.; Rampelli, S.; Orena, B.S.; Rengucci, C.; De Maio, G.; Barbieri, G.; Passardi, A.; Casadei Gardini, A.; Frassineti, G.L.; Gaiarsa, S.; et al. Shifts of Faecal Microbiota during Sporadic Colorectal Carcinogenesis. Sci. Rep. 2018, 8, 1-11. [CrossRef]

36. Louis, P.; Hold, G.L.; Flint, H.J. The gut microbiota, bacterial metabolites and colorectal cancer. Nat. Rev. Microbiol. 2014, 12, 661-672. [CrossRef]

37. Levy, M.; Kolodziejczyk, A.A.; Thaiss, C.A.; Elinav, E. Dysbiosis and the immune system. Nat. Rev. Immunol. 2017, 17, 219-232. [CrossRef]

38. Elinav, E.; Nowarski, R.; Thaiss, C.A.; Hu, B.; Jin, C.; Flavell, R.A. Inflammation-induced cancer: Crosstalk between tumours, immune cells and microorganisms. Nat. Rev. Cancer 2013, 13, 759-771. [CrossRef]

39. Brennan, C.A.; Garrett, W.S. Fusobacterium nucleatum-symbiont, opportunist and oncobacterium. Nat. Rev. Microbiol. 2019, 17, 156-166. [CrossRef]

40. Wu, J.; Li, Q.; Fu, X. Fusobacterium nucleatum Contributes to the Carcinogenesis of Colorectal Cancer by Inducing Inflammation and Suppressing Host Immunity. Transl. Oncol. 2019, 12, 846-851. [CrossRef]

41. Uitto, V.J.; Baillie, D.; Wu, Q.; Gendron, R.; Grenier, D.; Putnins, E.E.; Kanervo, A.; Firth, J.D. Fusobacterium nucleatum increases collagenase 3 production and migration of epithelial cells. Infect. Immun. 2005. [CrossRef] [PubMed]

42. Gur, C.; Ibrahim, Y.; Isaacson, B.; Yamin, R.; Abed, J.; Gamliel, M.; Enk, J.; Bar-On, Y.; Stanietsky-Kaynan, N.; Coppenhagen-Glazer, S.; et al. Binding of the Fap2 protein of fusobacterium nucleatum to human inhibitory receptor TIGIT protects tumors from immune cell attack. Immunity 2015, 42, 344-355. [CrossRef] [PubMed]

43. Brennan, C.A.; Garrett, W.S. Gut Microbiota, Inflammation, and Colorectal Cancer. Annu. Rev. Microbiol. 2016. [CrossRef] [PubMed]

44. Drewes, J.L.; White, J.R.; Dejea, C.M.; Fathi, P.; Iyadorai, T.; Vadivelu, J.; Roslani, A.C.; Wick, E.C.; Mongodin, E.F.; Loke, M.F.; et al. High-resolution bacterial $16 \mathrm{~S}$ rRNA gene profile meta-analysis and biofilm status reveal common colorectal cancer consortia. NPJ Biofilms Microbiomes 2017, 3, 34. [CrossRef] [PubMed]

45. Dejea, C.M.; Wick, E.C.; Hechenbleikner, E.M.; White, J.R.; Mark Welch, J.L.; Rossettid, B.J.; Peterson, S.N.; Snesrud, E.C.; Borisy, G.G.; Lazarev, M.; et al. Microbiota organization is a distinct feature of proximal colorectal cancers. Proc. Natl. Acad. Sci. USA 2014. [CrossRef]

46. Lazar, V.; Ditu, L.-M.; Gradisteanu Pircalabioru, G.; Gheorghe, I.; Curutiu, C.; Holban, A.M.; Picu, A.; Petcu, L.; Chifiriuc, M.C. Aspects of Gut Microbiota and Immune System Interactions in Infectious Diseases, Immunopathology, and Cancer. Front. Immunol. 2018, 9, 1-18. [CrossRef]

47. Feng, Q.; Liang, S.; Jia, H.; Stadlmayr, A.; Tang, L.; Lan, Z.; Zhang, D.; Xia, H.; Xu, X.; Jie, Z.; et al. Gut microbiome development along the colorectal adenoma-carcinoma sequence. Nat. Commun. 2015, 6. [CrossRef]

48. Lee, A.; Lee, Y.J.; Yoo, H.J.; Kim, M.; Chang, Y.; Lee, D.S.; Lee, J.H. Consumption of dairy yogurt containing Lactobacillus paracasei ssp. paracasei, Bifidobacterium animalis ssp. lactis and Heat-Treated Lactobacillus plantarum improves immune function including natural killer cell activity. Nutrients 2017, 9, 558. [CrossRef]

49. Skelly, A.N.; Sato, Y.; Kearney, S.; Honda, K. Mining the microbiota for microbial and metabolite-based immunotherapies. Nat. Rev. Immunol. 2019, 19, 305-323. [CrossRef]

50. O'Keefe, S.J.D. Diet, microorganisms and their metabolites, and colon cancer. Nat. Rev. Gastroenterol. Hepatol. 2016, 13, 691-706. [CrossRef]

51. Zitvogel, L.; Daillère, R.; Roberti, M.P.; Routy, B.; Kroemer, G. Anticancer effects of the microbiome and its products. Nat. Rev. Microbiol. 2017, 15, 465-478. [CrossRef] [PubMed]

52. Anand, S.; Kaur, H.; Mande, S.S. Comparative in silico analysis of butyrate production pathways in gut commensals and pathogens. Front. Microbiol. 2016, 7, 1-12. [CrossRef] [PubMed]

53. Gonçalves, P.; Araújo, J.R.; Di Santo, J.P. A cross-talk between microbiota-derived short-chain fatty acids and the host mucosal immune system regulates intestinal homeostasis and inflammatory bowel disease. Inflamm. Bowel Dis. 2018, 24, 558-572. [CrossRef] [PubMed] 
54. Geirnaert, A.; Calatayud, M.; Grootaert, C.; Laukens, D.; Devriese, S.; Smagghe, G.; De Vos, M.; Boon, N.; Van De Wiele, T. Butyrate-producing bacteria supplemented in vitro to Crohn's disease patient microbiota increased butyrate production and enhanced intestinal epithelial barrier integrity. Sci. Rep. 2017, 7, 1-14. [CrossRef] [PubMed]

55. Richards, J.L.; Yap, Y.A.; McLeod, K.H.; Mackay, C.R.; Mariño, E. Dietary metabolites and the gut microbiota: An alternative approach to control inflammatory and autoimmune diseases. Clin. Transl. Immunol. 2016, 5, e82. [CrossRef] [PubMed]

56. Zagato, E.; Pozzi, C.; Bertocchi, A.; Schioppa, T.; Saccheri, F.; Guglietta, S.; Fosso, B.; Melocchi, L.; Nizzoli, G.; Troisi, J.; et al. Endogenous murine microbiota member Faecalibaculum rodentium and its human homologue protect from intestinal tumour growth. Nat. Microbiol. 2020. [CrossRef]

57. Meeker, S.; Seamons, A.; Paik, J.; Treuting, P.M.; Brabb, T.; Grady, W.M.; Maggio-Price, L. Increased dietary vitamin D suppresses MAPK signaling, colitis, and colon cancer. Cancer Res. 2014. [CrossRef]

58. Derrien, M.; Collado, M.C.; Ben-Amor, K.; Salminen, S.; De Vos, W.M. The mucin degrader Akkermansia muciniphila is an abundant resident of the human intestinal tract. Appl. Environ. Microbiol. 2008. [CrossRef]

59. Zhou, X.; Chen, C.; Zhong, Y.N.; Zhao, F.; Hao, Z.; Xu, Y.; Lai, R.; Shen, G.; Yin, X. Effect and mechanism of vitamin $\mathrm{D}$ on the development of colorectal cancer based on intestinal flora disorder. J. Gastroenterol. Hepatol. 2019. [CrossRef]

60. Pauken, K.E.; Wherry, E.J. Overcoming T cell exhaustion in infection and cancer. Trends Immunol. 2015, 36, 265-276. [CrossRef]

61. Le, D.T.; Uram, J.N.; Wang, H.; Bartlett, B.R.; Kemberling, H.; Eyring, A.D.; Skora, A.D.; Luber, B.S.; Azad, N.S.; Laheru, D.; et al. PD-1 blockade in tumors with mismatch-repair deficiency. N. Engl. J. Med. 2015. [CrossRef] [PubMed]

62. Fong, W.; Li, Q.; Yu, J. Gut microbiota modulation: A novel strategy for prevention and treatment of colorectal cancer. Oncogene 2020, 39, 4925-4943. [CrossRef] [PubMed]

63. Colussi, D.; Fabbri, M.; Zagari, R.M.; Montale, A.; Bazzoli, F.; Ricciardiello, L. Lifestyle factors and risk for colorectal polyps and cancer at index colonoscopy in a FIT-positive screening population. United Eur. Gastroenterol. J. 2018. [CrossRef] [PubMed]

64. Sir Michael, M.; Tola, A.; Tim, B.; Junshi, C. World Cancer Research Fund / American Institute for Cancer Research. In Food, Nutrition, Physical Activity, and the Prevention of Cancer: A Global Perspective; AICR: Washington, DC, USA, 2007.

65. Castelló, A.; Amiano, P.; Fernández de Larrea, N.; Martín, V.; Alonso, M.H.; Castaño-Vinyals, G.; Pérez-Gómez, B.; Olmedo-Requena, R.; Guevara, M.; Fernandez-Tardon, G.; et al. Low adherence to the western and high adherence to the mediterranean dietary patterns could prevent colorectal cancer. Eur. J. Nutr. 2019. [CrossRef] [PubMed]

66. Statovci, D.; Aguilera, M.; MacSharry, J.; Melgar, S. The impact of western diet and nutrients on the microbiota and immune response at mucosal interfaces. Front. Immunol. 2017, 8, 838. [CrossRef]

67. Thøgersen, R.; Castro-Mejía, J.L.; Sundekilde, U.K.; Hansen, L.H.; Hansen, A.K.; Nielsen, D.S.; Bertram, H.C. Ingestion of an Inulin-Enriched Pork Sausage Product Positively Modulates the Gut Microbiome and Metabolome of Healthy Rats. Mol. Nutr. Food Res. 2018. [CrossRef]

68. Chai, W.; Morimoto, Y.; Cooney, R.V.; Franke, A.A.; Shvetsov, Y.B.; Le Marchand, L.; Haiman, C.A.; Kolonel, L.N.; Goodman, M.T.; Maskarinec, G. Dietary Red and Processed Meat Intake and Markers of Adiposity and Inflammation: The Multiethnic Cohort Study. J. Am. Coll. Nutr. 2017. [CrossRef]

69. Ley, S.H.; Sun, Q.; Willett, W.C.; Eliassen, A.H.; Wu, K.; Pan, A.; Grodstein, F.; Hu, F.B. Associations between red meat intake and biomarkers of inflammation and glucose metabolism in women1-3. Am. J. Clin. Nutr. 2014. [CrossRef]

70. Shen, Q.; Chen, Y.A.; Tuohy, K.M. A comparative in vitro investigation into the effects of cooked meats on the human faecal microbiota. Anaerobe 2010. [CrossRef]

71. O'Keefe, S.J.D.; Li, J.V.; Lahti, L.; Ou, J.; Carbonero, F.; Mohammed, K.; Posma, J.M.; Kinross, J.; Wahl, E.; Ruder, E.; et al. Fat, fibre and cancer risk in African Americans and rural Africans. Nat. Commun. 2015. [CrossRef]

72. Saracut, C.; Molnar, C.; Russu, C.; Todoran, N.; Vlase, L.; Turdean, S.; Voidazan, S.; Copotoiu, C. Secondary bile acids effects in colon pathology. Experimental mice study. Acta Cir. Bras. 2015. [CrossRef] [PubMed] 
73. Hofseth, L.J.; Hebert, J.R.; Chanda, A.; Chen, H.; Love, B.L.; Pena, M.M.; Murphy, E.A.; Sajish, M.; Sheth, A.; Buckhaults, P.J.; et al. Early-onset colorectal cancer: Initial clues and current views. Nat. Rev. Gastroenterol. Hepatol. 2020, 17, 352-364. [CrossRef]

74. Nicole, W. Secret ingredients: Who knows what's in your food? [published correction appears in Environ Health Perspect. 2013 Jun;121(6):A180]. Environ. Health Perspect. 2013, 121, A126-A133. [CrossRef] [PubMed]

75. Hata, K.; Kubota, M.; Shimizu, M.; Moriwaki, H.; Kuno, T.; Tanaka, T.; Hara, A.; Hirose, Y. Monosodium glutamate-induced diabetic mice are susceptible to azoxymethane-induced colon tumorigenesis. Carcinogenesis 2012. [CrossRef] [PubMed]

76. Bettini, S.; Boutet-Robinet, E.; Cartier, C.; Coméra, C.; Gaultier, E.; Dupuy, J.; Naud, N.; Taché, S.; Grysan, P.; Reguer, S.; et al. Food-grade TiO2 impairs intestinal and systemic immune homeostasis, initiates preneoplastic lesions and promotes aberrant crypt development in the rat colon. Sci. Rep. 2017. [CrossRef] [PubMed]

77. Urrutia-Ortega, I.M.; Garduño-Balderas, L.G.; Delgado-Buenrostro, N.L.; Freyre-Fonseca, V.; Flores-Flores, J.O.; González-Robles, A.; Pedraza-Chaverri, J.; Hernández-Pando, R.; Rodríguez-Sosa, M.; León-Cabrera, S.; et al. Food-grade titanium dioxide exposure exacerbates tumor formation in colitis associated cancer model. Food Chem. Toxicol. 2016. [CrossRef]

78. Chassaing, B.; Koren, O.; Goodrich, J.K.; Poole, A.C.; Srinivasan, S.; Ley, R.E.; Gewirtz, A.T. Dietary emulsifiers impact the mouse gut microbiota promoting colitis and metabolic syndrome. Nature 2015. [CrossRef]

79. Laudisi, F.; Di Fusco, D.; Dinallo, V.; Stolfi, C.; Di Grazia, A.; Marafini, I.; Colantoni, A.; Ortenzi, A.; Alteri, C.; Guerrieri, F.; et al. The Food Additive Maltodextrin Promotes Endoplasmic Reticulum Stress—Driven Mucus Depletion and Exacerbates Intestinal Inflammation. CMGH 2019. [CrossRef]

80. Akagawa, S.; Tsuji, S.; Onuma, C.; Akagawa, Y.; Yamaguchi, T.; Yamagishi, M.; Yamanouchi, S.; Kimata, T.; Sekiya, S.I.; Ohashi, A.; et al. Effect of delivery mode and nutrition on gut microbiota in Neonates. Ann. Nutr. Metab. 2019. [CrossRef]

81. Tamburini, S.; Shen, N.; Wu, H.C.; Clemente, J.C. The microbiome in early life: Implications for health outcomes. Nat. Med. 2016, 22, 713-722. [CrossRef]

82. Zhang, Q.; Berger, F.G.; Love, B.; Banister, C.E.; Murphy, E.A.; Hofseth, L.J. Maternal stress and early-onset colorectal cancer. Med. Hypotheses 2018. [CrossRef]

83. Van De Velde, C.J.H.; Boelens, P.G.; Borras, J.M.; Coebergh, J.W.; Cervantes, A.; Blomqvist, L.; Beets-Tan, R.G.H.; Van Den Broek, C.B.M.; Brown, G.; Van Cutsem, E.; et al. EURECCA colorectal: Multidisciplinary management: European consensus conference colon \& rectum. Eur. J. Cancer 2014. [CrossRef]

84. Kuipers, E.J.; Grady, W.M.; Lieberman, D.; Seufferlein, T.; Sung, J.J.; Boelens, P.G.; Van De Velde, C.J.H.; Watanabe, T. Colorectal cancer. Nat. Rev. Dis. Prim. 2015. [CrossRef]

85. Xie, Y.H.; Chen, Y.X.; Fang, J.Y. Comprehensive review of targeted therapy for colorectal cancer. Signal Transduct. Target. Ther. 2020, 5. [CrossRef]

86. Alexander, J.L.; Wilson, I.D.; Teare, J.; Marchesi, J.R.; Nicholson, J.K.; Kinross, J.M. Gut microbiota modulation of chemotherapy efficacy and toxicity. Nat. Rev. Gastroenterol. Hepatol. 2017, 14, 356-365. [CrossRef]

87. Kong, C.; Gao, R.; Yan, X.; Huang, L.; He, J.; Li, H.; You, J.; Qin, H. Alterations in intestinal microbiota of colorectal cancer patients receiving radical surgery combined with adjuvant CapeOx therapy. Sci. China Life Sci. 2019. [CrossRef]

88. Fei, Z.; Lijuan, Y.; Xi, Y.; Wei, W.; Jing, Z.; Miao, D.; Shuwen, H. Gut microbiome associated with chemotherapy-induced diarrhea from the CapeOX regimen as adjuvant chemotherapy in resected stage III colorectal cancer. Gut Pathog. 2019. [CrossRef]

89. Yu, T.C.; Guo, F.; Yu, Y.; Sun, T.; Ma, D.; Han, J.; Qian, Y.; Kryczek, I.; Sun, D.; Nagarsheth, N.; et al. Fusobacterium nucleatum Promotes Chemoresistance to Colorectal Cancer by Modulating Autophagy. Cell 2017. [CrossRef]

90. Zhang, S.; Yang, Y.; Weng, W.; Guo, B.; Cai, G.; Ma, Y.; Cai, S. Fusobacterium nucleatum promotes chemoresistance to 5-fluorouracil by upregulation of BIRC3 expression in colorectal caner. J. Exp. Clin. Cancer Res. 2019. [CrossRef]

91. Wallace, B.D.; Roberts, A.B.; Pollet, R.M.; Ingle, J.D.; Biernat, K.A.; Pellock, S.J.; Venkatesh, M.K.; Guthrie, L.; O'Neal, S.K.; Robinson, S.J.; et al. Structure and Inhibition of Microbiome $\beta$-Glucuronidases Essential to the Alleviation of Cancer Drug Toxicity. Chem. Biol. 2015. [CrossRef]

92. Villéger, R.; Lopès, A.; Carrier, G.; Veziant, J.; Billard, E.; Barnich, N.; Gagnière, J.; Vazeille, E.; Bonnet, M. Intestinal microbiota: A novel target to improve anti-tumor treatment? Int. J. Mol. Sci. 2019, 20, 4584. [CrossRef] [PubMed] 
93. Bhatt, A.P.; Pellock, S.J.; Biernat, K.A.; Walton, W.G.; Wallace, B.D.; Creekmore, B.C.; Letertre, M.M.; Swann, J.R.; Wilson, I.D.; Roques, J.R.; et al. Targeted inhibition of gut bacterial $\beta$-glucuronidase activity enhances anticancer drug efficacy. Proc. Natl. Acad. Sci. USA 2020. [CrossRef] [PubMed]

94. Markman, J.L.; Shiao, S.L. Impact of the immune system and immunotherapy in colorectal cancer. J. Gastrointest. Oncol. 2015. [CrossRef]

95. O’Neil, B.H.; Wallmark, J.M.; Lorente, D.; Elez, E.; Raimbourg, J.; Gomez-Roca, C.; Ejadi, S.; Piha-Paul, S.A.; Stein, M.N.; Abdul Razak, A.R.; et al. Safety and antitumor activity of the anti-PD-1 antibody pembrolizumab in patients with advanced colorectal carcinoma. PLoS ONE 2017. [CrossRef]

96. Overman, M.J.; McDermott, R.; Leach, J.L.; Lonardi, S.; Lenz, H.J.; Morse, M.A.; Desai, J.; Hill, A.; Axelson, M.; Moss, R.A.; et al. Nivolumab in patients with metastatic DNA mismatch repair-deficient or microsatellite instability-high colorectal cancer (CheckMate 142): An open-label, multicentre, phase 2 study. Lancet Oncol. 2017. [CrossRef]

97. Fessler, J.; Matson, V.; Gajewski, T.F. Exploring the emerging role of the microbiome in cancer immunotherapy. J. Immunother. Cancer 2019, 7, 108. [CrossRef]

98. Vétizou, M.; Pitt, J.M.; Daillère, R.; Lepage, P.; Waldschmitt, N.; Flament, C.; Rusakiewicz, S.; Routy, B.; Roberti, M.P.; Duong, C.P.M.; et al. Anticancer immunotherapy by CTLA-4 blockade relies on the gut microbiota. Science 2015. [CrossRef]

99. Sivan, A.; Corrales, L.; Hubert, N.; Williams, J.B.; Aquino-Michaels, K.; Earley, Z.M.; Benyamin, F.W.; Lei, Y.M.; Jabri, B.; Alegre, M.L.; et al. Commensal Bifidobacterium promotes antitumor immunity and facilitates anti-PD-L1 efficacy. Science 2015. [CrossRef]

100. Dubin, K.; Callahan, M.K.; Ren, B.; Khanin, R.; Viale, A.; Ling, L.; No, D.; Gobourne, A.; Littmann, E.; Huttenhower, C.; et al. Intestinal microbiome analyses identify melanoma patients at risk for checkpoint-blockade-induced colitis. Nat. Commun. 2016. [CrossRef]

101. Yang, J.; McDowell, A.; Kim, E.K.; Seo, H.; Lee, W.H.; Moon, C.M.; Kym, S.M.; Lee, D.H.; Park, Y.S.; Jee, Y.K.; et al. Development of a colorectal cancer diagnostic model and dietary risk assessment through gut microbiome analysis. Exp. Mol. Med. 2019. [CrossRef]

102. Mehta, R.S.; Nishihara, R.; Cao, Y.; Song, M.; Mima, K.; Qian, Z.R.; Nowak, J.A.; Kosumi, K.; Hamada, T.; Masugi, Y.; et al. Association of dietary patterns with risk of colorectal cancer subtypes classified by Fusobacterium nucleatum in tumor tissue. JAMA Oncol. 2017. [CrossRef]

103. Brandhorst, S.; Longo, V.D. Fasting and Caloric Restriction in Cancer Prevention and Treatment. Recent Results Cancer Res. 2016, 207, 241-266. [CrossRef]

104. Li, G.; Xie, C.; Lu, S.; Nichols, R.G.; Tian, Y.; Li, L.; Patel, D.; Ma, Y.; Brocker, C.N.; Yan, T.; et al. Intermittent Fasting Promotes White Adipose Browning and Decreases Obesity by Shaping the Gut Microbiota. Cell Metab. 2017. [CrossRef]

105. Zheng, X.; Zhou, K.; Zhang, Y.; Han, X.; Zhao, A.; Liu, J.; Qu, C.; Ge, K.; Huang, F.; Hernandez, B.; et al. Food withdrawal alters the gut microbiota and metabolome in mice. FASEB J. 2018. [CrossRef]

106. Hao, G.W.; Chen, Y.S.; He, D.M.; Wang, H.Y.; Wu, G.H.; Zhang, B. Growth of human colon cancer cells in nude mice is delayed by ketogenic diet with or without omega-3 fatty acids and medium-chain triglycerides. Asian Pacific J. Cancer Prev. 2015. [CrossRef]

107. Klement, R.J. Beneficial effects of ketogenic diets for cancer patients: A realist review with focus on evidence and confirmation. Med. Oncol. 2017, 34, 132. [CrossRef]

108. Klement, R.J.; Pazienza, V. Impact of Different Types of Diet on Gut Microbiota Profiles and Cancer Prevention and Treatment. Medicina 2019, 55, 84. [CrossRef]

109. Li, S.; Fu, C.; Zhao, Y.; He, J.; Tong, Q. Intervention with $\alpha$-ketoglutarate ameliorates colitis-related colorectal carcinoma via modulation of the gut microbiome. Biomed Res. Int. 2019. [CrossRef]

110. Van Raay, T.; Allen-Vercoe, E. Microbial Interactions and Interventions in Colorectal Cancer. Microbiol. Spectr. 2017. [CrossRef]

111. Destefano Shields, C.E.; Van Meerbeke, S.W.; Housseau, F.; Wang, H.; Huso, D.L.; Casero, R.A.; O’Hagan, H.M.; Sears, C.L. Reduction of Murine Colon Tumorigenesis Driven by Enterotoxigenic Bacteroides fragilis Using Cefoxitin Treatment. J. Infect. Dis. 2016. [CrossRef]

112. Boleij, A.; Hechenbleikner, E.M.; Goodwin, A.C.; Badani, R.; Stein, E.M.; Lazarev, M.G.; Ellis, B.; Carroll, K.C.; Albesiano, E.; Wick, E.C.; et al. The bacteroides fragilis toxin gene is prevalent in the colon mucosa of colorectal cancer patients. Clin. Infect. Dis. 2015. [CrossRef] 
113. Wu, S.; Rhee, K.J.; Albesiano, E.; Rabizadeh, S.; Wu, X.; Yen, H.R.; Huso, D.L.; Brancati, F.L.; Wick, E.; McAllister, F.; et al. A human colonic commensal promotes colon tumorigenesis via activation of T helper type 17 T cell responses. Nat. Med. 2009, 15, 1016-1022. [CrossRef]

114. Hamoya, T.; Miyamoto, S.; Tomono, S.; Fujii, G.; Nakanishi, R.; Komiya, M.; Tamura, S.; Fujimoto, K.; Toshima, J.; Wakabayashi, K.; et al. Chemopreventive effects of a low-side-effect antibiotic drug, erythromycin, on mouse intestinal tumors. J. Clin. Biochem. Nutr. 2017. [CrossRef]

115. Jin, J.-L.; Hua, G.-Q.; Meng, Z.; Gao, P.-J. Antibacterial Mechanisms of Berberine and Reasons for Little Resistance of Bacteria. Chin. Herb. Med. 2010. [CrossRef]

116. Yu, Y.N.; Yu, T.C.; Zhao, H.J.; Sun, T.T.; Chen, H.M.; Chen, H.Y.; An, H.F.; Weng, Y.R.; Yu, J.; Li, M.; et al. Berberine may rescue Fusobacterium nucleatum-induced colorectal tumorigenesis by modulating the tumor microenvironment. Oncotarget 2015. [CrossRef]

117. Bullman, S.; Pedamallu, C.S.; Sicinska, E.; Clancy, T.E.; Zhang, X.; Cai, D.; Neuberg, D.; Huang, K.; Guevara, F.; Nelson, T.; et al. Analysis of Fusobacterium persistence and antibiotic response in colorectal cancer. Science 2017. [CrossRef]

118. Zhao, S.; Gao, G.; Li, W.; Li, X.; Zhao, C.; Jiang, T.; Jia, Y.; He, Y.; Li, A.; Su, C.; et al. Antibiotics are associated with attenuated efficacy of anti-PD-1/PD-L1 therapies in Chinese patients with advanced non-small cell lung cancer. Lung Cancer 2019. [CrossRef]

119. Routy, B.; Le Chatelier, E.; Derosa, L.; Duong, C.P.M.; Alou, M.T.; Daillère, R.; Fluckiger, A.; Messaoudene, M.; Rauber, C.; Roberti, M.P.; et al. Gut microbiome influences efficacy of PD-1-based immunotherapy against epithelial tumors. Science 2018. [CrossRef]

120. Wang, Y.; Jiang, Y.; Deng, Y.; Yi, C.; Wang, Y.; Ding, M.; Liu, J.; Jin, X.; Shen, L.; He, Y.; et al. Probiotic Supplements: Hope or Hype? Front. Microbiol. 2020, 11, 1-9. [CrossRef]

121. Salminen, S.; Nybom, S.; Meriluoto, J.; Collado, M.C.; Vesterlund, S.; El-Nezami, H. Interaction of probiotics and pathogens-benefits to human health? Curr. Opin. Biotechnol. 2010, 21, 157-167. [CrossRef]

122. Paolillo, R.; Romano Carratelli, C.; Sorrentino, S.; Mazzola, N.; Rizzo, A. Immunomodulatory effects of Lactobacillus plantarum on human colon cancer cells. Int. Immunopharmacol. 2009. [CrossRef]

123. Rochat, T.; Bermúdez-Humarán, L.; Gratadoux, J.J.; Fourage, C.; Hoebler, C.; Corthier, G.; Langella, P. Anti-inflammatory effects of Lactobacillus casei BL23 producing or not a manganese-dependant catalase on DSS-induced colitis in mice. Microb. Cell Fact. 2007. [CrossRef]

124. Lenoir, M.; del Carmen, S.; Cortes-Perez, N.G.; Lozano-Ojalvo, D.; Muñoz-Provencio, D.; Chain, F.; Langella, P.; de Moreno de LeBlanc, A.; LeBlanc, J.G.; Bermúdez-Humarán, L.G. Lactobacillus casei BL23 regulates Treg and Th17 T-cell populations and reduces DMH-associated colorectal cancer. J. Gastroenterol. 2016. [CrossRef] [PubMed]

125. Jacouton, E.; Chain, F.; Sokol, H.; Langella, P.; Bermúdez-Humarán, L.G. Probiotic strain Lactobacillus casei BL23 prevents colitis-associated colorectal cancer. Front. Immunol. 2017. [CrossRef] [PubMed]

126. Chang, C.W.; Liu, C.Y.; Lee, H.C.; Huang, Y.H.; Li, L.H.; Chiau, J.S.C.; Wang, T.E.; Chu, C.H.; Shih, S.C.; Tsai, T.H.; et al. Lactobacillus casei Variety rhamnosus probiotic preventively attenuates 5-Fluorouracil/Oxaliplatin-induced intestinal injury in a syngeneic colorectal cancer model. Front. Microbiol. 2018, 9, 1-15. [CrossRef]

127. Zaharuddin, L.; Mokhtar, N.M.; Muhammad Nawawi, K.N.; Raja Ali, R.A. A randomized double-blind placebo-controlled trial of probiotics in post-surgical colorectal cancer. BMC Gastroenterol. 2019. [CrossRef]

128. Doron, S.; Snydman, D.R. Risk and safety of probiotics. Clin. Infect. Dis. 2015. [CrossRef] [PubMed]

129. Amoroso, C.; Perillo, F.; Strati, F.; Fantini, M.; Caprioli, F.; Facciotti, F. The Role of Gut Microbiota Biomodulators on Mucosal Immunity and Intestinal Inflammation. Cells 2020, 9, 1234. [CrossRef] [PubMed]

130. Davani-Davari, D.; Negahdaripour, M.; Karimzadeh, I.; Seifan, M.; Mohkam, M.; Masoumi, S.J.; Berenjian, A.; Ghasemi, Y. Prebiotics: Definition, types, sources, mechanisms, and clinical applications. Foods 2019, 8, 92. [CrossRef]

131. Fernández, J.; Moreno, F.J.; Olano, A.; Clemente, A.; Villar, C.J.; Lombó, F. A galacto-oligosaccharides preparation derived from lactulose protects against colorectal cancer development in an animal model. Front. Microbiol. 2018. [CrossRef]

132. Huang, G.; Khan, I.; Li, X.; Chen, L.; Leong, W.; Ho, L.T.; Hsiao, W.L.W. Ginsenosides Rb3 and Rd reduce polyps formation while reinstate the dysbiotic gut microbiota and the intestinal microenvironment in ApcMin/+ mice. Sci. Rep. 2017. [CrossRef] [PubMed] 
133. Xie, X.; He, Y.; Li, H.; Yu, D.; Na, L.; Sun, T.; Zhang, D.; Shi, X.; Xia, Y.; Jiang, T.; et al. Effects of prebiotics on immunologic indicators and intestinal microbiota structure in perioperative colorectal cancer patients. Nutrition 2019. [CrossRef] [PubMed]

134. Bultman, S.J.; Jobin, C. Microbial-derived butyrate: An oncometabolite or tumor-suppressive metabolite? Cell Host Microbe 2014, 16, 143-145. [CrossRef] [PubMed]

135. Bruno-Barcena, J.M.; Azcarate-Peril, M.A. Galacto-oligosaccharides and colorectal cancer: Feeding our intestinal probiome. J. Funct. Foods 2015, 12, 92-108. [CrossRef]

136. Krumbeck, J.A.; Rasmussen, H.E.; Hutkins, R.W.; Clarke, J.; Shawron, K.; Keshavarzian, A.; Walter, J. Probiotic Bifidobacterium strains and galactooligosaccharides improve intestinal barrier function in obese adults but show no synergism when used together as synbiotics. Microbiome 2018. [CrossRef]

137. Chen, X.; Wang, Q.; Shao, M.; Ma, L.; Guo, D.; Wu, Y.; Gao, P.; Wang, X.; Li, W.; Li, C.; et al. Ginsenoside $\mathrm{Rb} 3$ regulates energy metabolism and apoptosis in cardiomyocytes via activating PPAR $\alpha$ pathway. Biomed. Pharmacother. 2019. [CrossRef]

138. Hijová, E.; Szabadosova, V.; Štofilová, J.; Hrčková, G. Chemopreventive and metabolic effects of inulin on colon cancer development. J. Vet. Sci. 2013. [CrossRef]

139. Treepongkaruna, S.; Simakachorn, N.; Pienvichit, P.; Varavithya, W.; Tongpenyai, Y.; Garnier, P.; Mathiex-Fortunet, H. A randomised, double-blind study of polyethylene glycol 4000 and lactulose in the treatment of constipation in children. BMC Pediatr. 2014. [CrossRef]

140. Mosca, F.; Gianni, M.L.; Rescigno, M. Can Postbiotics Represent a New Strategy for NEC? Adv. Exp. Med. Biol. 2019, 1125, 37-45. [CrossRef]

141. Tian, Y.; Xu, Q.; Sun, L.; Ye, Y.; Ji, G. Short-chain fatty acids administration is protective in colitis-associated colorectal cancer development. J. Nutr. Biochem. 2018. [CrossRef]

142. Kanehara, K.; Ohnuma, S.; Kanazawa, Y.; Sato, K.; Kokubo, S.; Suzuki, H.; Karasawa, H.; Suzuki, T.; Suzuki, C.; Naitoh, T.; et al. The indole compound MA-35 attenuates tumorigenesis in an inflammation-induced colon cancer model. Sci. Rep. 2019. [CrossRef]

143. Chung, I.C.; Ouyang, C.N.; Yuan, S.N.; Lin, H.C.; Huang, K.Y.; Wu, P.S.; Liu, C.Y.; Tsai, K.J.; Loi, L.K.; Chen, Y.J.; et al. Pretreatment with a heat-killed probiotic modulates the NLRP3 inflammasome and attenuates colitis-associated colorectal cancer in mice. Nutrients 2019, 11, 516. [CrossRef]

144. Zhuo, Q.; Yu, B.; Zhou, J.; Zhang, J.; Zhang, R.; Xie, J.; Wang, Q.; Zhao, S. Lysates of Lactobacillus acidophilus combined with CTLA-4-blocking antibodies enhance antitumor immunity in a mouse colon cancer model. Sci. Rep. 2019. [CrossRef]

145. Gupta, A.; Saha, S.; Khanna, S. Therapies to modulate gut microbiota: Past, present and future. World J. Gastroenterol. 2020, 26, 777-788. [CrossRef]

146. Wang, Z.; Hua, W.; Li, C.; Chang, H.; Liu, R.; Ni, Y.; Sun, H.; Li, Y.; Wang, X.; Hou, M.; et al. Protective Role of Fecal Microbiota Transplantation on Colitis and Colitis-Associated Colon Cancer in Mice Is Associated With Treg Cells. Front. Microbiol. 2019, 10, 1-14. [CrossRef]

147. Chang, C.W.; Lee, H.C.; Li, L.H.; Chiau, J.S.C.; Wang, T.E.; Chuang, W.H.; Chen, M.J.; Wang, H.Y.; Shih, S.C.; Liu, C.Y.; et al. Fecal microbiota transplantation prevents intestinal injury, upregulation of toll-like receptors, and 5-fluorouracil/oxaliplatin-induced toxicity in colorectal cancer. Int. J. Mol. Sci. 2020, 21, 386. [CrossRef]

148. Ding, C.; Tang, W.; Fan, X.; Wu, G. Intestinal microbiota: A novel perspective in colorectal cancer biotherapeutics. Onco. Targets. Ther. 2018, 11, 4797-4810. [CrossRef]

149. Koliarakis, I.; Messaritakis, I.; Nikolouzakis, T.K.; Hamilos, G.; Souglakos, J.; Tsiaoussis, J. Oral bacteria and intestinal dysbiosis in colorectal cancer. Int. J. Mol. Sci. 2019, 20, 4146. [CrossRef]

150. Raskov, H.; Burcharth, J.; Pommergaard, H.C. Linking gut microbiota to colorectal cancer. J. Cancer 2017, 8, 3378-3395. [CrossRef]

151. Zheng, D.W.; Dong, X.; Pan, P.; Chen, K.W.; Fan, J.X.; Cheng, S.X.; Zhang, X.Z. Phage-guided modulation of the gut microbiota of mouse models of colorectal cancer augments their responses to chemotherapy. Nat. Biomed. Eng. 2019. [CrossRef]

(C) 2020 by the authors. Licensee MDPI, Basel, Switzerland. This article is an open access article distributed under the terms and conditions of the Creative Commons Attribution (CC BY) license (http://creativecommons.org/licenses/by/4.0/). 